\title{
Employment of Geoinformation Technologies in Historical Researches Experience of Kazan (Volga Region) Federal University
}

\author{
Dina A. Mustafina ${ }^{1}$, Olga V. Luneva ${ }^{1} \&$ Luiza K. Karimova ${ }^{1}$ \\ ${ }^{1}$ Kazan (Volga Region) Federal University, Kazan, Russia \\ Correspondence: Dina A. Mustafina \& Olga V. Luneva, Kazan (Volga Region) Federal University, \\ Kremlyovskaya Street 18, Kazan 420008, Russia. E-mail: maktub29@yandex.ru
}

Received: April 14, 2015 Accepted: April 20, 2015 Online Published: April 27, 2015

doi:10.5539/jsd.v8n4p70 URL: http://dx.doi.org/10.5539/jsd.v8n4p70

\begin{abstract}
Relevance of the topic is due to the prevailing in modern science trend - complex study of society, not only in time but also in space, established thanks to the convergence and integration of Arts and Sciences. The paper aims to describe our own experience of association within the framework of a single information field of full-text data sources, mainly registration, accounting and statistics data (cadastres, scribe and census books) and maps to represent in terms of spatial coordinates the social stratification of the city Sviyazhsk and its surroundings in the XVII century. The leading method in the research of this problem is that of geo-information technologies. The main results of this work were the establishment of historical sources database of the period under study, data formalization of the written sources, compiling the geographic basis of geo-information system (GIS), digitization and creation of vectorized base of geo-data (BGD), which allows to localize and identify the settlement of Sviyazhsk County. The paper materials will be useful for further research and for model development of a settlement structure, farm tenure and land use, social stratification of the population and multifaceted relationships of towns and villages (peasantry) in the Middle Volga area in the second half of the XVII century.
\end{abstract}

Keywords: Modern information technologies, computer technologies, geo-information system, social stratification, Sviyazhsk District (County), Central Volga area, cartographic materials, cadastres

\section{Introduction}

\subsection{Relevance of the Problem}

Possibilities of interdisciplinary researches, multifunctionality of GIS attract the increasing number of historians. Researches, connected with the spatial analysis (in Russia, as well as abroad) are conducted in two directions: 1) theoretical, in the frames of which the GIS use bases are specified and adjusted in the history research (Owens, 2008; Gregory \& Cooper, 2009; Igonin, 2011; Knowles, 2013) and 2) practical, when authors describe their own experience and specific cases of GIS application, problems they faced during research, and the way of their solution (Raymond, 2011; Boeckel \& Otterstrom, 2009; Arakawa \& Nicholson, 2010; Rygalova \& Chibisov, 2012). In 1960s large data files were processed by means of the electronic computer machine and at the boundary of 1980 and 1990 successful attempts "to refer" data of demographic character to the area were made in the USA and Canada. Establishment of the international Association "History \& Computing" in 1986 stipulated an increase in the historical researches done with application of the information technologies (IT). So far in Western Europe, North America and Australia large-scale complexes of cartographical historical data and GIS on history of certain continents, countries and regions are created. The Russian branch of the given organization "History \& Computing" Association was established in 1992, and in many respects defines the main directions of application of IT for the Russian scientists. In recent years the "GIS and Their Use in Historical Researches" becomes one of the main directions. So far a number of researches with the use of GIS have been conducted in national science (Bryukhanova, 2012; Kanishchev, 2012; Khayrutdinov, 2014; Kovaleva, et al, 2015; Shaidullina et al, 2015; Gafiyatullina, et al, 2015). Barnaul, Moscow, Nizhny Novgorod and others became the recognized centers of application of modern computer technologies in humanitarian researches.

\subsection{Support of Interdisciplinary Projects}

GIS perspective application is realized by the administrative structures supervising scientific researches and 
supporting the projects connected with the GIS problematics by means of various funds (Russian State Scientific Fund, Russian Federal Property Fund, Intas, etc.). Thus, in 2012 within the federal grant program "Scientific and Educational Research Specialists of Innovative Russia" for 2009-2013 the Ministry of Education and Science of the Russian Federation supported the "Stratification Interaction of the City and Village in the Transcultural Region in the second half of the XVI-XVIII centuries" project conducted by group of researchers of the Kazan federal university (KFU).

\subsection{Purpose and Research Problems}

The work was aimed at integration of information resources: cartographical and diverse written sources and innovative technologies for the subsequent creation of a geographic information system of the operated databases on social stratification of the population in Volga-Ural region from the moment of its entry into structure of the Russian state and prior to Peter I reformations, and also on implementation of the preliminary spatial analysis of cartographical and text data. Creation of the GIS-project demanded the fulfillment of the following tasks: 1) selection and systematization of the information sources to carry out the quantitative data analysis, 2) formation of databases; 3) drawing up a cartographical underlay; 4) carrying out the spatial analysis of cartographical data.

\subsection{Features of Sviyazhsk City and Its District}

In the second half of the XVI century, the city of Sviyazhsk represented a fortified place of military and administrative designation where mainly military population lived. Formation its district (county) happened instantaneously: the whole right bank or Mountainside of the Volga River made a special area or region ruled by governor, which passed into possession of the Russian state. After the conquest of Kazan, it was transformed into the county with the center in Sviyazhsk. In the process of construction of new fortified cities at the Mountain side and establishment of the adjacent territory subordinated to them this administrative and territorial unit was split up, there appeared independent Cheboksary, Kokshaysk, Tsarevokokshaysk, Tsarevosanchursk, Tsivilsk and Yaransk districts. The part of Sviyazhsk district appeared also as a part of the Kazan and Simbirsk districts. At the beginning of the XVIII century, Sviyazhsk district became the smallest in the Kazan province. In 1708, the city was attributed to Kazan, in 1719, it became the center of Sviyazhsk province, in 1781, it was the district center of the Kazan region ruled by governor, in 1796 it became Kazan government, in 1920, it was the center of Sviyazhsk canton, in 1927 - the county of the same name, which in 1931 was liquidated. The city of Sviyazhsk was transformed to the rural settlement by the Presidium resolution of the All-union Central Election Committee of February 1, 1932 (Mustafina, 2011).

\section{Materials and Methods}

\subsection{Features of the Software}

Methodology of the research was developed proceeding from need of the above tasks solution. The software of the methods was made by the Microsoft Office package MS Excel spreadsheets. Creation of GIS project of the Sviyazhsk District was made by means of the basic software ArcGIS 10.2 (ESRI, The USA), the full-function geographical information system possessing a wide tool kit of mapping and geo-data processing. The choice of this ArcGIS 10.2 system as the main information product of the project was due to the following features distinguishing it from other GIS: 1) functionality, which ArcGIS 10.2 provides, surpasses all known analogs; 2) ways of the organization, management and data compilation are so effective that maintaining GIS of the project doesn't require the highly skilled personnel; 3) scalability of the system, which means that a personal user at a local computer as well as remote users can work with GIS project of a map service, bases of geo-data, models of the analysis and other components of geographical information.

\subsection{Difficulties in Delimitation of the District}

Certain difficulties in studying of evolution of a landowners' landscape and social levels of country and urban population were caused by uncertainty and extreme mobility of district borders of the XVI-XVII centuries. Within this research we were guided by the spatial framework designated by resources materials of the middle XVII century. As Sviyazhsk District was understood as a whole territory of the Mountainside which was a part of four Stans (camps): Podgorodny, Kirelsky, Muratovsky and Kalininsky. This territory was irrigated with the rivers of the Volga River basin: the Sviyaga confluent and its confluents - the Anchigirk, Arya, Berlya, Buva, Kachemirovka, Kubnya, Kuvshinovka, Kulanga, Kurela, Labyshka, Lomovka, Malaya Birlya, Meminka, Morkvashka, Muralinka, Sekerka, Serbinka, Sulitsa, Tavlinka, Taranya, Tenki, Urzhumka, Utyashka, Chichirka, Sharatka, Shishka, Shusherma and some other rivers. 


\subsection{Search and Identification Resource Materials}

For the solution of an objective at the first stage of the study, researches were carried out in three archives - in the Russian state archive of ancient acts (RSAAA, Moscow), National archive of the Republic of Tatarstan (NA RT), Department of manuscripts and rare books of Scientific library of the Kazan (Volga region) federal university. Cadastres materials became a database basis for studying of the historical regularities in Sviyazhsk District of the second half of the XVI-XVIII centuries in spatial terms. During archival searches we managed to find out about twenty large-scale cadastres actions of the second half of the XVI-XVII centuries. However, texts of only five descriptions survived (apart from copies of various censuses): 1) cadastre of the city of Sviyazhsk and district of the 60th of the XVI century. (Frantsuzova, 2002); 2) census book of the city and district of the 40th of the XVII century (Russian state archive of ancient acts, further: RSAAA, fund 1209, inventory 1, storage units 6448,6447$) ; 3$ ) two inventory books on materials of the field book of the district of the 50-60th of the XVII century (Mustafina, 2004); 4) census book of Sviyazhsky Posad of the 70th of the XVII century (RSAAA, fund 1209, inventory 1, storage unit 6451); 5) cadastre and boundary book of the Podgorodny Stan (camp) of the district of the middle 80th of the XVII century (RSAAA, fund 1209, inventory 1, storage unit 435, 645).

\subsection{Geographic Information System Basis}

The basis of GIS was made by modern topography of the district, objects of modern building and infrastructure, and also by various cartographic materials of the XVIII-XIX centuries, including topographic maps and schemes. First of all, it is five maps of the XVIII century and six maps of the XIX century reflecting the Kazan province in general. All of them to different extent of informational content allow to restore the spatial organization of settlements in dynamics. Localization of settlements was also made with application of historical city maps of Sviyazhsk of 1796, 1829, 1847, 1869 and schematic map of the XIX century, the year of mapping is unknown. The collection of plans of general land surveying Sviyazhsk District of the XVIII-XIX centuries and the collection of historical topographic maps and plans on the territory of the island and its district of the above-mentioned years are so far digitized. The scanned images of maps and plans were vectorized in software packages of EASY TRACE 8.8 and ArcGIS 10.2. Thanks to digitization of the collection of general land plans surveying Sviyazhsk District of the XVIII-XIX centuries and the collection of historical topographic maps and plans on the territory of the island-city of Sviyazhsk and its district, we succeeded to create the vectorized base of geo-data (BGD) allowing localizing and identifying the settlements of Sviyazhsk District.

\section{Results}

\subsection{Complex of the Revealed Materials of Cadastres and Their Information Potential}

Formation of historical sources database of the period for GIS of Sviyazhsk District of XVII assumed formalization of the revealed written sources data, on the one hand, and drawing up a geographical basis on the other hand.

The first survived description of Sviyazhsk District is the field and boundary book made within the gross letter by the boyars of the higher rank N. V. Borisov and D. A. Kikin in 1565-1567. The list of this book made in 1810 by the collegiate registrar P. Trofimov from earlier list was found in Sviyazhsk by professor of the Kazan Theological Academy I. Yakovkin and was printed in 1909. This description represents the fixing of results of the Mountainside colonization, carried out during 15-17 years from the moment of the city of Sviyazhsk foundation. The contained data on settlements, the administrative-territorial arrangement of the district, forms of land tenure and social structure of the population, was processed by us for the purpose of their formalization by means of the MS Excel program. The description consists of two parts: 1) descriptions of the city with the market, trading quarter and settlements and 2) descriptions of private property and church-monastery lands. The topographical objects within fortifications or in "city" (temples, prisons, tsar's bright room, clerk's log hut, government facilities, corn lofts, small shops) and in the trading quarter (temples, tsar's bright room, baths, the Tatar yard, brewery, bazaar, small shops, booths, log huts with ceilings) were of interest to us. The copyists described 59 inhabited settlements and 1 barren land: registered land possession of 4 provinces, 1 clerk, 28 children of boyars (4 old and 24 new residents), two monasteries - Sviyazhsk God Mother (Dormition) and Sviyazhsk Trinity-Sergiyev monastery. Besides the types of settlements, the books material reflects their distribution by Stans (camps): Podgorodny, Kamensk Kirelsky, Muratovsky, thereby it gives the chance to have a clear idea of the territory and to designate borders of camps and the district in general, allows to track origin and development of specific inhabited settlements, helps to reveal the disappeared settlements, degree of the territory development. Besides this important for mapping information, the source contains data on the size, composition and categories of service class population, as well as of their salaries and degree of human occupancy, qualitative structure of local lands, labour density. It also lists the types of agricultural lands of the estate, inhabited and 
unoccupied households of field peasants, rent size from the stallion. The source also contains retrospective information on the former status of lands and the previous owner. Thereby the book gives the chance to judge sources, circumstances, ways and methods of local lands formation and service class corporation of the district, the reasons and ways of transition of lands from hand to hand (Frantsuzova, 2002).

In 1593/94 all patrimonial possession of the Troitse-Sergiyev monastery, including in Sviyazhsk and Kazan districts were considered. Registration material remained in the form of copies (sheets) from this description made by the scribe N. Sverchkov and fastened by the clerk B. Ivanov. We know of the existence of these cadastre materials from researches, however texts of sheets haven't been published yet. We managed to reveal the record extracts from census books of T.I. Yesipov and the scribe V. Ivanov reflecting the initial stage of formation of possession of the Troitse-Sergiyev monastery in Sviyazhsk District. Data of copyists help to localize patrimonial possession of Sviyazhsk "branch" of this corporation, scales, direction, degree of intensity of colonization, nature of agricultural development (primary or repeated) the Kazan territory in the first four decades after the conquest of Kazan (Shumakov, 1911).

In the middle of the XVII century within seven years, from 1646 to 1652, the team of copyists at first under the leadership of I.M. Anichkov, and after his death of I. Frantszbekov worked in Sviyazhsk District. The text of the description has not survived, but we managed to reveal the little-known inventory books made on their materials. In one of the inventory books made by G. Protopopov the list of possession of the service class Mirzas and Tatars (Mustafina, 2004) was presented, in another - lands of the Russian landowners. Lists represent result of the cadastre text processing of the "papers and measures" for the purpose of the concise information receiving for convenience of the user - the employees of the office and government agents directed for work on the next description. Record sheets of the source are extremely unified; material is extremely compact and dense. Though the draftsman of the inventory books adheres to the structure of original field books, there is no information given on fractional and detailed inventory of grounds, statement of justification of the possessory rights, data about territory density, calculations or land descriptions on tax purposes, boundaries, data on economic constructions, enumeration of the households of the dependent population and the people and peasants occupying them. The whole material of these two lists reflects the picture of private land tenure in the district which developed in the middle of the XVII century. Data contained in them is recorded by the Stans (camps) Podgorodny, Muratovsky, Kamensk, Kirelsky, within the Stans by settlements. In the latter records are given by name, surname, with the indication of the social status (Mirza, Tatar, non-verst, minor, Sviyazhsk citizen, soldier, foreigner, etc.), and service class.

Despite the known incompleteness (absence of the cadastre descriptions of lands and population), the survived sources help to recreate, first of all, the structure of land tenure which developed in the region and the stratification of society caused by it. It forms irreplaceable basis for definition of results of feudal and religious policy of the imperial government in the second half of XVI, the first half of the XVII century in the mid-Volga region in general, and in Sviyazhsk District in particular, for clarification of features of colonization process, sources of villages establishment, their localization, drawing up genealogy of childbirth, etc.

\subsection{Maps as a Way of Identification and Description of Spatial Objects}

The picture of the spatial organization of settlements in the middle and the last quarter of the XVIII century was recreated on the basis of information of two atlases published in 1745, 1792, 1800 and two special maps of the Kazan province of 1765 and 1779.

In the structure of the first atlas, "The Atlas of Russia..." published in 1745 by the Russian Academy of Sciences and recognized as the first official atlas there was a number of maps of the European part of Russia executed on the scale of about 34 versts in inch. Its 9th sheet represented "A kingdom of Kazan with roundabout provinces and part of the Volga River". In spite of the fact that the Atlas became the result of long-term tool shootings of Russian lands, is unique in cartographical and art relations, it contains the minimum information. Only borders of districts, a hydrographic network of the region and the largest settlements were reflected, however their location was not marked precisely, the network of overland thoroughfares wasn't traced, forests were designated without indication of contours, etc. (The kingdom of Kazan with a devious provinces and part of the Volga River (1745/2007).

One of 44 sheets of the second atlas was made by a mathematician, a geographer, a cartographer and an astronomer A. Vilbrekht by 1786, and published in 1792 "The map of the Kazan region ruled by governor" (sheet 31). Reflection of the administrative arrangement of the Russian Empire which was installed after "The new provision on provinces" 1775 was a peculiar feature of the atlas. According to which Sviyazhsk District was a part of the Kazan region ruled by governor. Though the map marked mainly big rivers, large and average by 
number of residents settlements, it gives a certain notion of places of the greatest concentration and character of settlements (Vilbreht, 1792).

Information on the mentioned maps wassupplemented by data of 10 versts "Map of the oak groves and the other wild woods of Kazan, Nizhny Novgorod, Orenburg provinces", made in 1765 by the lieutenant colonel A.I. Svechin. As he was authorized to make audit of the ship woods and to find out the reasons of impoverishment of the state peasants of Kazan province he paid a special attention to fixing the territories covered with the woods, and settlements of the state peasants, the rivers, lakes, the main overland thoroughfares (National Archives of the Republic of Tatarstan). Specification of spatial data was made also with application of material of "The general map of the Kazan province composed on the latest news in 1779 by Fyodor Cherny" and the map of the Kazan province with reflection of 10 districts made by A. Vilbrekht and published in 1800 (sheet 28). Cartographical sources of the Kazan province of the XVIII century were used in the retrospective purposes: for localization of settlements and a reconstruction of an integral picture of the population movement in the second half of the XVI-XVII centuries. However they allow to define not only the system of movement, but also help to reveal the direction of population movement and also to track change of types of settlements (their "density", integration or, on the contrary, desolation), change of their name and toponymy of the district in general.

Material of maps of the XVIII century, was supplemented and corrected by data of the Kazan province maps of the XIX centuries which copies were transferred to us by the employee of the museum of archeology of Institute of archeology (Kazan) H.M. Abdullin, and also data of city maps of Sviyazhsk and maps of Sviyazhsk District, the part of copies was kindly provided to us by the staff of the Museum of "Island Sviyazhsk".

First of all, it is necessary to mention the "General map of the Kazan province of 1822 " made by the colonel V.P. Pyadyshev. It is a part of "The geographical atlas of the Russian Empire, the kingdom of Poland and Grand Principality of Finland 1820-1827" (sheet 39). The careful sketch of post paths with the indication of stations and distances between them, and large passable roads was characteristic feature of the map. On the borders of districts, the most significant settlements were noted as well as important topographical objects (fortresses, monasteries) and industrial institutions (factories and plants) are designated.

Information we were interested in is contained in the "Gribovsky Atlas", the black-and-white map taken from "The memorable book of the Kazan province for 1861-1862", the 30 versts colour map of the Kazan province made by the court adviser P. Zhiganov which were issued during works on a land surveying of the European part of the Russian Empire. "Gribovsky Atlas" was distinguished by reflection of mainly state possession, the rivers with the available piers, post roads, city centers of administrative and territorial units, settlements where district, volost and rural boards settled down. On the black-and-white map practically all settlements were specified, country roads, placement of volost boards, post stations, venues of markets and functioning of plants were marked. P. Zhiganov's map reports on borders of camps and on differentiation of settlements of population (Abdullin, Mustafina \& Sitdikov, 2013).

Two more maps of the Kazan province are of particular interest to us. One of the maps is a part of "The detailed atlas of the Russian Empire ...", published in 1876 by private cartographical institution of A.A. Ilyin (listed as 23rd). It should be noted that maps of the Russian provinces, districts and areas with plans of the provincial centers, and also thematic (administrative, hydrographic, ethnographic, etc.) maps of Russia entering this atlas are considered the most detailed and accurate maps of provinces (Ilyin, 1876/2007). The second map was a part of published by military and topographical department of the General staff under edition of the famous Russian cartographer, surveyor, infantry general I.A. Strelbitsky "The special map of the European Russia" of 1875 (scale: 10 versts in inch (in $1 \mathrm{~cm} \mathrm{4,2} \mathrm{km).} \mathrm{This} \mathrm{map} \mathrm{consisting} \mathrm{of} 178$ sheets was the most detailed Atlas of the European part of the Russian Empire. The territory of Sviyazhsk District was divided between two sheets, 90 and 109 (Strelbitsky, 1875, 1919). Special maps of Sviyazhsky District also were drawned to the analysis (RGADA, fund 1356).

\section{Discussions}

Acquaintance of the Russian historians-researchers with works of the foreign colleagues using geographic information systems in the researches took place nearly two decades ago. So far there is a tradition of the GIS technology use in archaeological researches, in studying of the spatial organization of the population, in research of dynamics of social and demographic processes, etc. Scientific centers, whose employees actively resort to use of GIS (Moscow, Barnaul, Tambov, Petrozavodsk, etc.) have been identified, there are associations uniting the experts applying GIS-technologies, the special magazine "History and Computer" is issued. However researches with the use of GIS-technologies are still of single character and carried out at the micro level. The Middle Volga region has not become a subject of similar researches that in a certain degree caused us to address to the 
specified latest technologies in the field of information processing and to creation of the operated database on material of Sviyazhsk and its district in the XVII century.

\section{Conclusion}

As spatial historical models can be created at both macro (the countries, continents), and at the micro-level (certain areas, districts), we made an attempt to resort to the use of GIS in research of settlement structure, forms of land tenure and land use and social stratification of the population of separate administrative and territorial units of the Volga-Ural region caused by them, on the example of Sviyazhsk District of the second half of the XVI, the beginning of the XVIII centuries. The need of carrying out researches in this direction is caused by existence of numerous hypothetical assumptions of placement and social and economic structure of settlements and lack of exact representations of placement of social level in settlements during the medieval period. Traditional approach to processing and the analysis of the historical sources reflecting relationship of rural society and the city did not allow us to find out the factors uniting and separating country and urban population to reveal features of integration of various levels (cities and villages, service class people and peasantry, the population of Posad and monasteries) of pagan and Muslim district of the Christian state. Systematization with application of the theory and methods of written sources data information, mainly from the cadastres and census books, allowed us to create the operated database, in a new way reflecting a state and development of multiethnic and poly-confessional Central Volga area in the second half of the XVI-XVII centuries. Application of various cartographic materials allowed us to create a scientific and technical electronic basis for creation and replenishment of GIS of the operated databases on the spatial organization of Sviyazhsk District, landowners' landscape and social strata of country and urban population, colonization and economic development of the district. Research showed that within the XVII century in Sviyazhsk District there were parallel and interconnected processes of formation and change of administrative-territorial structure and development of feudal land tenure. In Sviyazhsk District there were no palace administrative establishments, and there were possessory, church and monastic and yasak (state) lands and settlements. This territory was included at once in the system of feudal land tenure, but prior to the beginning of the XIX century remained the periphery. In social and economic structure of the cities there were serious changes caused by economic and trade contacts of the city and village. By the end of the XVII century the city of Sviyazhsk was transformed to the center of trade involving the population of the district (county) in the activity and in the system of the nation-wide market. These processes were followed by change of class structure, of both Sviyazhsk, and rural settlements.

\section{Recommendations}

Studying interaction of the city and village of the considered district isn't finished yet. Further research will be directed on the definition of dynamics of quantitative and qualitative parameters of social level in the city and the district, clarification of influence on interaction of various social groups, distribution of the political power by the center (Sviyazhsk) on the district, methods and ways of realization of the economic power, evolution of social and economic communications between the city and the village, consideration of the reasons influencing their strengthening and recession.

\section{Acknowledgments}

The work is performed according to the Russian Government Program of Competitive Growth of Kazan Federal University

\section{References}

Abdullin, H. M., Mustafina, D. A., \& Sitdikov, A. G. (2013). Formation of a database of historical sources the second half of XVI the first half of the XVII century for the geographic information system of the Kazan region. Scientific notes of the Kazan University, 155(3), 66-78.

Arakawa, F., \& Nicholson, C. (2010). Prehistoric resource procurement in the central Mesa Verde region: A study of human mobility and social interactions using GIS. International Journal of Humanities and Arts Computing, 3, 85-100. http://dx.doi.org/10.3366/ijhac.2009.0010

Boeckel, M. A., \& Otterstrom, S. M. (2009). From wilderness to megalopolis: A comparative analysis of county level sex ratios in the United States from 1790 to 1910 using a Historical GIS. Social Science Computer Review, 27, 297-312. http://dx.doi.org/10.1177/0894439308329758

Bryukhanova, E. A. (2012). Information technology in the study of the structure and professional employment for the 1897 census. Newsletter of the Association "History and Computer", 38, 133-134.

Frantsuzova, E. B. (Eds.). (2002). Extract from the scribes and the landmark book, the Sviyazhska and 
Sviyazhsky County okolnichy N.V. Borisov and DA Kikina teammates: city Svijazhsk. In M. Ya. Volkov, \& Z. V. Dmitrieva (Eds.), Russian city of the XVI century: Proceedings of scribal descriptions (pp. 337-390). Moscow.

Gafiyatullina, A. Z., Nikonova, T. V., Vagin, S. G., Kharisova, R. R., Pavlova, E. I., Khayrutdinov, R. R., \& Ishmuradova I. I. (2015) Organization of Controlling the Intellectual Potential of Company Personnel. Review of European Studies, 7(4), 13-19. http://dx.doi.org/10.5539/res.v7n4p13

Gregory, I. N., \& Cooper, D. (2009). Thomas Gray, Samuel Taylor Coleridge and Geographical Information Systems: A literary GIS of two Lake District tours. International Journal of Humanities and Arts Computing, 3, 61-84. http://dx.doi.org/10.3366/ijhac.2009.0009

Igonin, A. V. (2011). Geographic information systems and experience of their use in the works of foreign and domestic historians. Kazan science, 11, 20-22. Retrieved March 17, 2012, from http://www.kazanscience.ru/sbornik

Ilyin, A. (1876/2007). Map Kazan province with the plan of the city. In A. Ilyin (Eds.), Detailed atlas of the Russian Empire with plans to major cities (Facsimile edition 1876) (p. 20). St. Petersburg: Alfaret. $\mathrm{http}: / / 85 \mathrm{mb}$. net/index.php?newsid=68018

Kanischev, V. V. (2012). Experience in the use of modern information technologies in projects for the historical geography. Newsletter of the Association "History and Computer", 39, 71-74.

Khayrutdinov, R. R. (2014). Museum Conference of 1926 in Kazan. World Applied Sciences Journal, 31(2), 193-195.

Knowles, A. K. (2013). The contested nature of historical GIS. International Journal of Geographical Information Science, 28, 206-211. http://dx.doi.org/10.1080/13658816.2013.850696

Kovaleva, N. I., Valeyeva, N. Sh., Avilova, N. L., Kharisova, G. M., Khayrutdinov, R. R., Khairullina, E. R., \& Shaikhlislamov, A. K. (2015). Recommended Practices for Improving the Competitiveness of the Russian Education Services Market under the Conditions of the International. Review of European Studies, 7(4), 1-5. http://dx.doi.org/10.5539/res.v7n4p1

Mustafina, D. A. (2004). Perechnevaya book Sviyazhsky County: According to the materials scribe's description 1646-1652. Kazan.

Mustafina, D. A. (Eds.). (2011). Code written sources on the history of the Tula region. Kazan.

National Archives of the Republic of Tatarstan. Fund 324. Inventory 324. Case 1097.

Owens, J. B. (2008). What Historians Want from GIS. Essays on Geography and GIS, ESRI, 35-47. Retrieved August 25, 2012, from http://www.esri.com/news/arcnews/summer07articles/what-historians-want.html

Raymond, A. (2011). Denny Regrade, 1893-2008: A case study in Historical GIS. Social Science History, 35, 571-597. http://dx.doi.org/10.1215/01455532-1381850

Rossiiskii gosudarstvennyi arkhiv drevnix aktov (RGADA). Fond Gubernskie, uezdnje i gorodskie karty, plany i atlasy Generalnogo mezhevanija 1356, opis 1, dela 1196, 1199, 1200, 1203, 1204.

Rossiiskii gosudarstvennyi arkhiv drevnix aktov (RGADA). Fond Pomestnogo prikaza 1209, opis 1, delo 6448, list 367, 614-1271; delo 6447, list 9-306 (n.d.).

Rossiiskii gosudarstvennyi arkhiv drevnix aktov (RGADA). Fond Pomestnogo prikaza 1209, opis 1, delo 6451, list $1-70$.

Rossiiskii gosudarstvennyi arkhiv drevnix aktov (RGADA). Fond Pomestnogo prikaza 1209, opis 1, delo 435, list 123-206; delo 645, list 502-582.

Rygalova, M. V., \& Chibisov, M. E. (2012). Application of GIS technology in the study of local history (for example Volchikhinsky District Altai Krai). Newsletter of the Association "History and Computer", 38 , $142-144$

Shaidullina, A., Pavlova, N., Minsabirova, V., Burdukovskaya, E., Yunusova, A., Letyaev, V., \& Afanasev, A.S. (2015). Integration Processes In Education: Classification of Integration Types. Review of European Studies, 7(4), 27-31. http://dx.doi.org/10.5539/res.v7n4p27

Shumakov, S. A. (1911). Sotnitsy, ratification and entry (Vol. 6). Moscow.

Strelbitsky, I. A. (Eds.). (1875). A special map of European Russia with the adjacent part of Western Europe and 
Asia Minor (sheet 109). St. Petersburg: Military-topograficheskey department Military Topographic Directorate of the General Staff, Russia. Retrieved from http://85mb.net/index.php?newsid=51608

Strelbitsky, I. A. (Eds.). (1919). A special map of European Russia with the adjacent part of Western Europe and Asia Minor (sheet 90). St. Petersburg: Military-topograficheskey department Military Topographic Directorate of the General Staff, Russia. http://85mb.net/index.php?newsid=51608

The kingdom of Kazan with a devious provinces and part of the Volga River (1745/2007). Atlas of Russia, consisting of nineteen special maps representing the Russian Empire with the border lands, composed according to the rules and the latest geographical observation, with applications though the General Map of the Great Empire sion, diligence and works of the Imperial Academy of Sciences. (Facsimile edition 1745) (Sheet 9), Petersburg: Alfaret. Retrieved October 16, 2012, from http://tat-map.ru/index/0-4

Vilbreht, A. M. (1792). Map of Kazan governorship. Russian atlas of maps consisting of forty-four and forty-two governorship Empire divides. Retrieved October 16, 2012, from http://www.runivers.ru/lib/book3295/16672/

\section{Copyrights}

Copyright for this article is retained by the author(s), with first publication rights granted to the journal.

This is an open-access article distributed under the terms and conditions of the Creative Commons Attribution license (http://creativecommons.org/licenses/by/3.0/). 